MIDPI

MOL2NET, International Conference Series on Multidisciplinary Sciences http://sciforum.net/conference/mol2net-03

\title{
sciforum
}

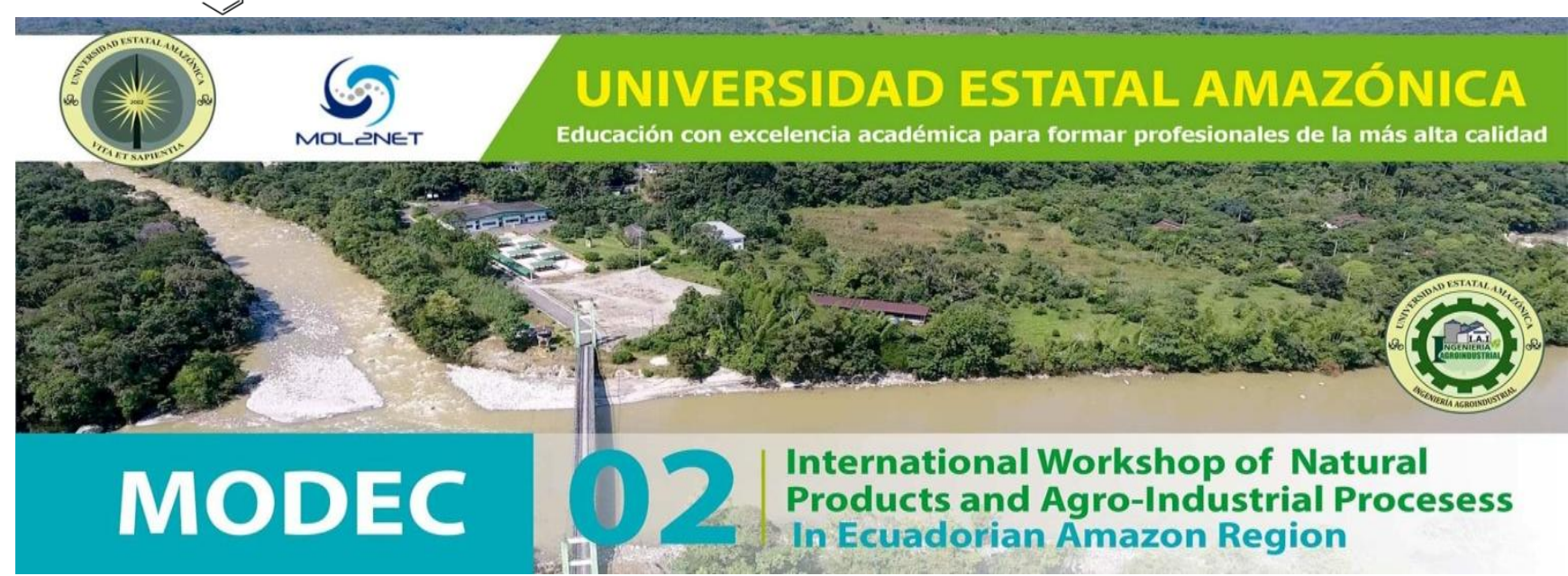

\section{Rural community's territorial system dynamics at the Anzu river valley in the Amazon territory to propose change scenario}

Authors: Ruth Irene Arias-Gutiérrez (rarias@uea.edu.ec)a , Roberto González-Sousa (rgsousa@geo.uh.cu), Angelina Herrera-Sorzano (aherrera@geo.uh.cu) $)^{\mathrm{b}}$, Manuel Pérez-Quintana (mperez@uea.edu.ec)a , Elisa de la Bien Aparecida López-Cosme (elopez@uea.edu.ec) $)^{\mathrm{a}}$.

aProfessors-Researchers. Universidad Estatal Amazónica, Km. 21/2, vía Puyo a Tena (Paso Lateral). Tel. (+593) 32-888-118 / 32-889-118. Postal Code: 160150. Puyo, Ecuador.

brofessors-Researchers. Facultad de Geografía. Universidad de La Havana, Calle L. No. 353 e/21 y 23, Vedado. Tel. (+537) 8304076. Código postal: 10400. Cuba. 


\section{Graphical Abstract}

\section{Krchwacommunity's}

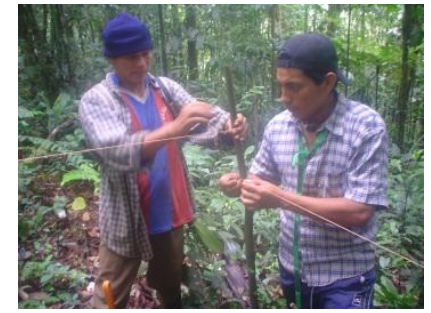

Mestizos and Kichwa

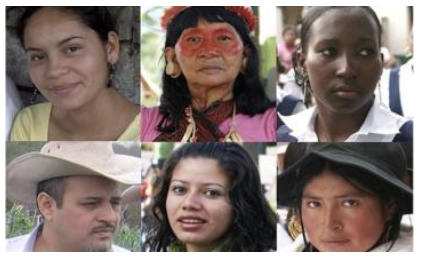

Jungle and animal protection
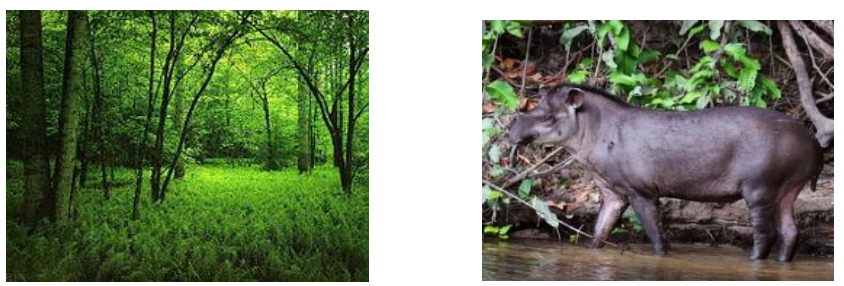

Alliances and synergies

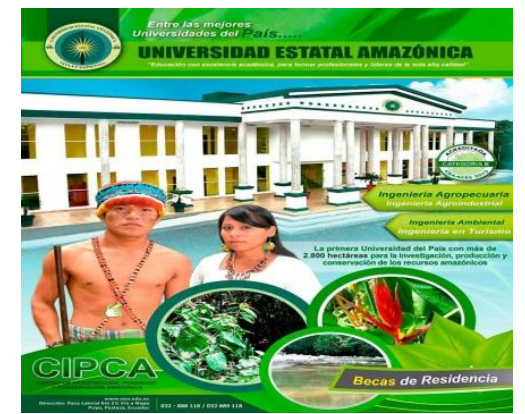

Abstract.

A Kichwa community's dynamics at the river Anzu valley, in the Ecuadorian Amazon territory, to propose change scenarios is analyzed. The Anzu valley, populated by sustainable mestizos and Kichwa communities, autonomous, in harmony with nature, visible in the different products that they process from environment resources, live in their legalized territories, where government entities recognized the Kichwa ancestral property. The Kichwa achieved to articulate strategies for the biodiversity resources use, whose beneficial repopulation and processing may allowed obtaining their maintenances, the payment of their labor and income families. The knowledge system and the people's cultural identity in social harmony with nature are revalued. The territory possession and its security, together with the ancestral knowledge, management systems understanding of the environment resources, which come from a cultural tradition, wisdom in the jungle associated with new technological forms that provide economic income through the local resources processing, gives communities the opportunity to renew their pride, which contributes to the consistent use of their environment. It recovers and intensifies the agro ecosystem management, gradually increases the promissory species sowing and repopulation, animals and plants. The desired scenario implies a sustainable, autonomous functioning, with alliances and synergies.

Keywords: Kichwa communities, Amazon territorial systems, sustainability.

\section{Introduction}

In the world, indigenous peoples have lived on the nature products, many peoples migrate when the area resources are depleted, until the natural environment is regenerated and can be used again. Indigenous peoples' livelihoods are altered by processes related to development, political decisions, natural resources exploitation, mining, urbanization, modernization, infrastructure development, 
climate change and global warming (Dublin \& Tanaka, 2014; Akerlof et al., 2010). As a plurinationalintercultural rights \& justice State, Ecuador is made up of 15 original nations or indigenous nationalities, as well as Afro-Ecuadorian populations, montuvias (peasants from the coastal region), white and mestizo people (Constitución de la República del Ecuador, 2008).

There is now an international trend towards the indigenous people's collective rights recognition, whose main claims are the land recovery from which they were dispossessed; the collective rights to own, develop, use, control and occupy their lands and traditional resources involve the integrity and conservation of their natural habitat, including environmental protection. Some Latin American countries have made significant progress in this regard, through constitutionally recognizing the indigenous people's legal personality, which has not been possible in other countries. The right to respect, integrity and conservation of habitats and natural resources are closely linked to the indigenous peoples and environmental protection (Gaona, 2013).

The Amazon western portion, including Ecuador, is one of the most bio diverse areas on the planet, home to several indigenous peoples, it maintains intact portions of jungle and it has a high probability of stabilizing climate conditions face to global warming problems (Smith \& Leiserowitz, 2014; Gainette, 2009).

In the present evolution analysis researching from Amazon community's development and its consequences in the Ecuadorian Amazonian territory, it is contextualizing the original indigenous nation territory of Ecuadorian Amazonian Kichwa and the conceptualizing of the change scenarios pertinence. The aim was to analyze a Kichwa community's dynamics at the river Anzu valley, in the Ecuadorian Amazon territory.

\section{Materials and Methods}

Six communities located in the ancestral territory of the original Ecuadorian Kichwa Amazonian nation are studied, from Northeaster Tzawata, until the Southwester Veinticuatro de Mayo communities (table 1), located in the low, medium and high levels of the Anzu River valley; the communities settled since the end of the 19th century, come from the Napo province. They are rural communities, representative of a common origin and express a vulnerability gap in relation to the initiatives developed by the local governments and the planning units.

Table 1. Location of selected communities in the study.

\begin{tabular}{lccccccc}
\hline Community & $\mathbf{Z}^{\text {a }}$ & Altitude & North & East & \multicolumn{2}{c}{ Parish } & \multicolumn{2}{c}{ Canton } & Province \\
\hline Tzawata & 18 & 508 & 9869264 & 179523 & $\begin{array}{l}\text { Carlos Julio } \\
\text { Arosemena }\end{array}$ & $\begin{array}{c}\text { Carlos Julio } \\
\text { Arosemena }\end{array}$ & Napo \\
\hline Wayuri & 17 & 1200 & 9862500 & 831306 & Mera & Mera & Pastaza \\
\hline For de Bosque & 18 & 752 & 9858789 & 170876 & Santa Clara & SantaClara & Pastaza \\
\hline Boayaku & 18 & 808 & 9854478 & 168082 & Teniente Hugo Ortiz & Pastaza & Pastaza \\
\hline $\begin{array}{l}\text { Unión de Llandia } \\
18\end{array}$ & 1099 & 9851931 & 169383 & Teniente Hugo Ortiz & Pastaza & Pastaza \\
\hline $\begin{array}{l}\text { Veinticuatro de } \\
\text { Mayo }\end{array}$ & 17 & 994 & 9845509 & 832473 & Fátima & Pastaza & Pastaza \\
\hline
\end{tabular}

${ }^{a}$ Universal Transverse Mercator South zone

The studied communities are located from 508 to 1200 meter over sea level, in the eastern foothills of the central Andes, south of the sub-Andean zone identified as Napo Uprising, on hydromorphic alluvial soils with a forest vocation, volcanic origin and conservation purposes; soils formed by the dejection cones in the Amazon foothills, as a result of the fusion of plio-quaternary glaciers and volcanic and seismic activity (Senplades; Instituto Geográfico Militar, 2010). Rainfall is never less 
than $4000 \mathrm{~mm}$ per year and exceeds $6000 \mathrm{~mm}$ per year; the average temperature is set between $20 \&$ $24^{\circ} \mathrm{C}$; the climate is tropical humid; the topography corresponds to broken and collapsed terrain, with slopes varying from relatively flat terrain in the lower areas to inclinations of 70 degrees or more at higher altitudes. Landscapes prevailing are permanent humid tropics (González and Salinas, 2010). The life area corresponds to pre-montane rainforest (Cañadas, 1983); plant formation is always Piedmont green forest (Sierra, 1999). The region contains just 5.06\% of the national population, with densities from 2.82 to 15.38 inhabitants per $\mathrm{km}^{2}$. The research goes through surveys to the families and their leaders, interviews to former settlers, and discussion in nine workshops.

\section{Results and Discussion}

The Kichwa communities have the chakra system installed in primary or secondary forest to take advantage of the organic fertility of the forest, it's cultivated for several years and is nourished with the system of ushun (crop regeneration); when it loses fertility, it becomes in purun containing the remaining planted species: fruit, medicinal, forest, like the ayllu's (family lineage) and the communities' work testimony, footprints in the territory for recognition of limits. This indigenous system in the vast Amazonian territory remains imbricated with the environmental system and provides subsistence sources and benefic species. According Escobar (2002) biodiversity conservation is only ensured with local cultures and communities focus. Kichwa culture is prevalent in the communities, with their systems of treatment of the environment, farms, cultural ceremonies of healing and evidences of the ancestral territories in petroglyphs.

The indigenous communities said that the jungle or Pachamama is their pharmacy, supermarket, school, security system and origin of power. Although they maintain large amounts of forests and compensation programs exist as "forest partners", they did not receive payments in cash or others for the environmental system maintenance, water protection, biodiversity conservation, Oil Company's compensation or mining companies, reforestation, agroforestry or any other. Only the Tzawata community received in 2012 a tourism group interested in learning about life in the community, from its own reality. It was investigated the benefit that the environmental system provided to families, by extracting products for domestic use and for the market, assigning a monetary quantification for each element used; for example for wood to cook, considered a free service of the forest, the family estimated an amount or cost in money on the assumption of how much can pay or how much can be sold the fuel wood unit. Table 2 indicates the products extracted from the forest in 2012 and their quantification in money; it is a quantification of the goods or products they use, although they do not mean cash income in all cases for all families.

Table 2. Products of the forest used in 2012.

\begin{tabular}{llc}
\hline \multicolumn{1}{c}{ Community } & \multicolumn{1}{c}{ Forest products, medicinal, other uses, wild animals. } & $\begin{array}{c}\text { Annual familiar } \\
\text { Income (\$) }\end{array}$ \\
\hline Tzawata & $\begin{array}{l}\text { Fine woods of chuncho, ahuano, cedar, laurel; fibers; barks and medicines, leaves, } \\
\text { guayusa, cat's claw; guanta; edible fruits of hungurahua. }\end{array}$ & 520 \\
\hline Wayuri & Wood to cook; chonta edible fruit; Chugchuhuazo medicine and Guayusa. & 215 \\
\hline For de Bosque & $\begin{array}{l}\text { Cinnamon and laurel fine woods; soft pihue wood; wood to cook; animals } \\
\text { armadillo, guatusa, guanta; chambira and pita fibers; turmeric and ishpingo species; } \\
\text { cat's claw medicine, drago blood. }\end{array}$ & 533 \\
\hline Boayaku & $\begin{array}{l}\text { Cinnamon, chuncho and laurel fine woods; soft pihue wood; sajino; chambira fiber; } \\
\text { mushukhuan medicine. }\end{array}$ & 960 \\
\hline Unión de Llandia & Canelo hardwood; soft pihue wood. & 813 \\
\hline $\begin{array}{l}\text { Veinticuatro de } \\
\text { Mayo }\end{array}$ & Canelo hardwood; soft pihue wood; wood to cook; palmito; guatusas; monkey & 160 \\
\hline
\end{tabular}


Land, forest and water are more than a resource for peasants and indigenous people, it is relevant as a subject, part of its culture and identity; any local development project considered within the framework of a strategy must be oriented towards the biodiversity conservation, support the production of communities beginning with traditional systems research in their orientation both to the market and to the domestic economy. The territorial system under study has great biodiversity, not intensively occupied according to its morphology, becomes a priority area for establishing local development projects, but these can't ignore the intrinsic values associated with biodiversity, such as the principles of local autonomy, knowledge, identity and economy (Escobar, 2010).

Table 3 presents the synthesis of environmental system strategic diagnosis, with the structural and conjuncture keys that define the current territorial model. However, it is necessary to emphasize that structural keys generalization based on the environmental system strategic diagnosis does not mean that the impacts and responses are common to all communities, which is evidenced in the differences reported in the variables analyzed in the surveys. In the knowledge axis, economy and food sovereignty, the action lines include the systematization, recovery and socialization of values and the management and conservation forms of the territory and its resources; modeling the dynamics of the local, family, community and market economy (Coraggio, 2013, Figueroa, 2013); the definition of symbolic action forms, values and new economic practices in relations within the communities and in front of the market. In this axis the possibility of undertaking agro ecological, plant therapeutic, tourism (Tuncay, 2013), heritage recognition and social, cultural and demographic studies can be evaluated, in a strategic relationship with the Amazon State University.

Table 3. Environmental system strategic diagnosis

\section{Structural keys}

Potentials

- Key position in the Kichwa ancestral territory, near services axis.

- Plant cover compatible with assigned conservation vocation.

- Richness landscapes, biodiversity and associated knowledge of species uses, fine and soft woods, fibers, medicinal plants, foods, rituals, cosmetics, wild animals and natural fishing.

- Roads network do not reach all communities that does not allow the colonizing possession ambition over the territory.

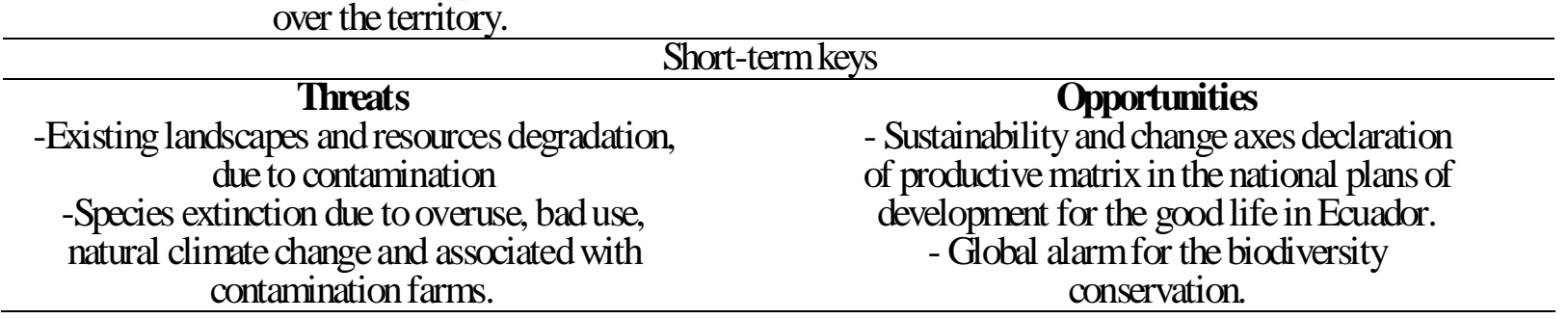

\section{Conclusions}

Products extracted in the communities from the forest in 2012 and their quantification in money do not mean cash income by these ones, but jungle does offers products to families for domestic or merchant use. Communities with more knowledge that conserve jungle, have Kichwa tradition and that are near ways have more income than those that have minor jungle resources and those that are far away from

\section{Weaknesses}

communities, which makes it difficult to trade. 
the roads. The reduction of the resources of the forest and the reduction of the cultural tradition causes scenarios of change toward the greater commodification of products.

Structural keys generalization based on the environmental system strategic diagnosis revels potentials use from the own jungle and local people knowledge, but it is possible replant richness resources that give incomes to families; however, the structural keys generalization not mean that the impacts and responses are common to all communities, which is evidenced in the differences reported in the variables analyzed in the surveys. Change scenarios needs too the strategic collaboration among communities, university and development actors.

\section{References}

Akerlof, K; DeBono, R; Berry, P.; Leiserowitz, A; Roser-Renouf, C.; Clarke, K; Rogaeva, A; Nisbet, M; Weathers, M. and Maibach, E. (2010). Public Perceptions of Climate Change as a Human Health Risk: Surveys of the United States, Canada and Malta. Int. J. Environ. Res. Public Health, 7, 2559-2606; doi:10.3390/ijerph7062559.

Cañadas, R. 1983. El Mapa bioclimático y biogeográfico del Ecuador. Quito-Ecuador.

Constitución de la República del Ecuador. (2008). Quito: Asamblea Nacional Constituyente.

Coraggio, J. (2013). “Tres corrientes en la ESS". Temas, cultura, ideología, sociedad. 75: 4-11 julyseptember. Cuba.

Dublin, D. \& Tanaka, N. (2014). Indigenous agricultural development for sustainability and "Satoyama". Geography, Environment, Sustainability. v 7 (2). 86-95. Moscow, Russia: Faculty of Geography, Lomonosov Moscow State University and Institute of Geography of the Russian Academy of Sciences.

Escobar, A (2002). Globalización, desarrollo y modernidad. Planeación, participación y desarrollo. Medellín: Corporación región. 9-32. On line: june 19th/2014 available in www.oei.es/salacti/escobar.htm.

Escobar, A. 2010. Una minga para el postdesarrollo: lugar, medio ambiente y movimientos sociales en las transformaciones globales. Lima: Universidad Nacional Mayor de San Marcos, Facultad de Ciencias Sociales, Programa Democracia Y Transformación global.

Figueroa, M. 2013. “Las tres economías”.- Opening Conference III Local Development International Congress, Palacio de Convenciones de La Habana. Cuba.

Gainette, L. (2009). Evolución del paisaje amazónico desde el Precámbrico. Rev. Bras. Geocienc. 41, (4): 654-661.

Gaona, G. (2013). El derecho a la tierra y protección del medio ambiente por los pueblos indígenas. Nueva Antropología, 26(78): 141-161. ISSN 0185-0636. Available in: http://www.redalyc.org/articulo.oa?id=15929710007.

González, R; Salinas, E. (2010). Geografía de América Latina. La Habana: Editorial Félix Varela.

Senplades; IGM. (2010). Atlas geográfico de la república del Ecuador, población, producción, medio ambiente. [CD-ROM]. Quito. Pp: 6-40.

Sierra, R. (Ed). 1999. Propuesta Preliminar de un Sistema de Clasificación de Vegetación para el Ecuador Continental. Proyecto INEFANGEF-BIRF y EcoCiencia. Quito, Ecuador. 
Smith, N. \& Leiserowitz, A. (2014). The Role of Emotion in Global Warming Policy Support and Opposition. Risk Anal. 34(5): 937-948. Doi: 10.1111/risa.12140.

Tuncay, V. B. 2013. De la ruta del sol a la ruta del Spondylus: valorización turística de las identidades indígenas de la costa ecuatoriana por la patrimonialización de un objeto arqueológico (Ecuador). III Congreso Internacional de Desarrollo Local. Palacio de Convenciones de La Habana, Cuba, 06 a 09 de noviembre 2013, pp 2737-2746. 